\title{
A FORMAÇÃO DOS ENGENHEIROS QUE PARTICIPARAM DA COMISSÃO DE MELHORAMENTOS DO RIO SÃO FRANCISCO (1883-1896)
}

\author{
$\underline{\text { Ariane Mendes Rocha }}{ }^{1}$; Ivoneide de França Costa ${ }^{2}$
}

1. Bolsista PIBIC/FAPESB, Graduanda em Engenharia Civil, Universidade Estadual de Feira de Santana, e-mail: ariane.mendes10@gmail.com

2. Orientadora, Departamento de Letras e Artes, Universidade Estadual de Feira de Santana, e-mail: neidefc@uefs.com.br

PALAVRAS-CHAVE: Formação; Engenheiros; Ensino

\section{INTRODUÇÃO}

No ano de 1792, no Rio de Janeiro, foi criada a primeira academia de ensino com o nome de Real Academia de Artilharia, Fortificação e Desenho marcando o início formal do curso de Engenharia Civil no Brasil (TELLES, 1994; 87). Com o passar dos anos a Academia passou por sucessivas reformas currículares e transformações. Aos poucos foi se aperfeiçoando ao ensino técnico-prático de Engenharia, o ensino era voltado para as obras de melhoramentos do país. Assim, muitos engenheiros recém-formados começaram a atuar nas Comissões de Melhoramentos (COELHO, 1999; 198).

Em 1883 o Governo Imperial criou a Comissão de Melhoramentos do Rio São Francisco (CMRSF), visava uma melhoria na locomoção de pessoas e mercadorias. O objetivo da CMRSF era executar obras de desobstrução de canais no Rio São Francisco. Para realizar as obras necessitava-se de um conhecimento minuncioso do rio, para isso foram contratados engenheiros para a realização de estudos e execução das obras( MACHADO, 2002).

A primeira equipe da CMRSF do Rio São Francisco foi composta pelo Engenheiro Antônio Plácido Peixoto do Amarante ( Engenheiro Chefe); Theodoro Fernandes Sampaio ( $1^{\circ}$ Engenheiro Ajudante); Albuquerque F. Ramos (Engenheiro Condutor); João Emiliano Amarante (Engenheiro Condutor); Evaristo Galvão (Engenheiro Auxiliar); Reginaldo Candido da Silva (Engenheiro Auxiliar); Foligonio Magalhães de Souza e Moisés Deschamps de Montmorencey ( Desenhistas) (COSTA,2013).

Diante da necesssidade de identificar os engenheiros que fizeram parte da primeira equipe da CMRSF, este trabalho objetivou verificar o ano de formação de cada engenheiro; identificar a instituição onde ocorreu a formação e verificar os currículos das instituições de ensino que os engenheiros passaram.

\section{MATERIAIS E MÉTODOS}

A obtenção do ano de formação dos engenheiros, da identificação, das instituições de ensino e dos currículos foi feito através de pesquisas em fontes bibliográficas vinculadas ao projeto, como também em outras fontes bibliográficas.

\section{RESULTADOS E DISCUSSÃO}

Foi possível identificar os engenheiros que participaram da CMRSF. Os engenheiros João Emiliano Amarante, Reginaldo Candido da Silva, Foligonio Magalhães de Souza e Moysés Deschamps não foram identificados os respectivos anos de formação, as instituições de ensino e os currículos. Os demais engenheiros foram identificados: Antônio Peixoto do Amarante; formou-se em Ciências Físicas e Matemáticas no ano de 1877 pela Escola Central. 
Theodoro Fernandes Sampaio; ingressou na Escola Central em 1872, cursou disciplinas da área de Ciências Físicas e Naturais, no ano de 1874 com a separação da Escola Central, bacharelouse em Engenharia Civil. Augusto Ferreira Ramos; formou-se em Engenharia Civil pela Escola Politécnica em 1882. No geral, os engenheiros que participavam da CMRSF eram formados pela Escola Central ou pela Escola Politécnica, os seus respectivos currículos eram reformulados de acordo com a necessidade das obras do país.

\section{CONSIDERAÇÕES FINAIS}

Baseado nos resultados obtidos nesta pesquisa, os engenheiros que participaram da primeira equipe da CMRSF, no geral, concluíram o curso de Engenharia Civil pela Escola Central ou pela Escola Politécnica.

\section{REFERÊNCIAS}

TELLES, Pedro Carlos da Silva. História da Engenharia no Brasil (séculos XVI e XIX). Rio de Janeiro: Clavero, 1994. $2^{\text {a }}$ edição. p. 87.

MACHADO, Fernando da Matta. Navegação do rio São Francisco. Rio de Janeiro: Topbooks. 2002, 433p.

COELHO, Edmundo Campos. As Profissões Imperiais: medicina, engenharia e advocacia no Rio de Janeiro, 1822-1930. Rio de Janeiro: Record, 1999, p. 198.

COSTA, Ivoneide de França. Comissão Hidráulica do Império (1879-1880): profissionalização e técnica a serviço dos melhoramentos no século XIX. Tese ( Doutorado em História das Ciências) - Programa de pós graduação em História das ciências e das Saúde - COC - Fiocruz, Rio de Janeiro, 2013. p. 187). 